\title{
Microleakage evaluation of composite restorations submitted to load cycling
}

\section{Avaliação da microinfiltração de restaurações em compósito submetidas à ciclagem mecânica}

\author{
Luis Felipe Jochims SCHNEIDER \\ Rubens Nisie TANGO \\ Graduate student - Dental Materials - Dental School of Piracicaba - UNICAMP - Brazil
}

\author{
Fábio Machado MILAN \\ George Valdemar MUNDSTOCK \\ Professor of Dentistry - University of Santa Cruz do Sul - UNISC - Brazil
}

\section{Simonides CONSANI}

Titular Professor of Dental Materials - Departament of Restorative Dentistry - Dental School of Piracicaba - UNICAMP - Brazil

\section{Mário Alexandre Coelho SINHORETI}

Professor of Dental Materials - Departament of Restorative Dentistry, Dental School of Piracicaba - UNICAMP - Brazil

\begin{abstract}
The aim of this research was to evaluate the load cycling influence in resin composite restorations through marginal leakage analysis, in enamel and cementum. Forty bovine incisors were allocated in four groups (n=10): I-Z250 resin composite / Single Bond adhesive system; II - Charisma resin composite / Gluma One Bond adhesive system; III - Z250 resin composite /Single Bond adhesive system submitted to 1,000 cycles (10Kgf); group IV - Charisma resin composite I Gluma One Bond adhesive system submitted to 1,000 cycles. The class V restorations were located at cementum-enamel junction and the load was applied on the incisal edge. The samples were immersed in $2 \%$ buffered methylene blue solution. The samples were cross-sectioned and the leakage, which received a score, was evaluated through stereomicroscope (45 X ). Data were submitted to Kruskal-Wallis' test (5\%). Analysis showed no statistical differences among margins localized in enamel or in cementum, for loaded and unloaded groups ( $p>0,05)$. However, enamel showed better results than cementum in the same sample $(p<0,05)$.Load cycling did not increase the microleakage in enamel or in cement margins. Comparing the infiltration degree in the same sample, the staining solution penetration was higher in cementum margins, for both loaded and unloaded groups.
\end{abstract}

\section{UNITERMS}

Composite resins; mechanics, cycling; microleakage

\section{INTRODUCTION}

Tooth-colored restorative materials based on dimethacrylate monomers have increasingly been used to replace missing tooth structures and to modify tooth esthetics. Resin composites are, essentially, the linking of fillers and matrix through a silane agent. The matrix consists of organic monomers, a polymerization inhibitor, and an activation/initiation system (ANUSAVICE ${ }^{1}, 1998$ ). Moreover, the resin matrix is a fluid component that becomes rigid when polymerized. It is due to the free radical formation that induces covalent linking between the organic molecules. These unions lead to macromolecules formation named polymers (GUGGENBERGER \& WEINMANN $\left.{ }^{10}, 2000\right)$. During this connection formation there is some volumetric reduction of the material. That occurs because the intermolecular 
distance of the isolated monomers is greater than the distance among the molecules connected by covalent linking (SAKAGUSHI ${ }^{23}$, 1999; FERRA$\left.\mathrm{CANE}^{8}, 2001\right)$. This volumetric reduction, known as polymerization shrinkage, is inherent to the material (ASMUSSEN ${ }^{2}, 1975$ ) and, if this polymerization shrinkage exceeds the adhesive strength between dental tissue/adhesive system/composite, a gap formation probably will occur leading to fluid, bacteria, and organic materials penetration, known as microleakage (DAVIDSON et al. ${ }^{5}, 1984$; CRIM \& GARCIA-GODOY $\left.{ }^{3}, 1987\right)$.

Frequently, resin composites are used in cervical lesions (carious or non-carious lesions), which need restorative treatments. Studies about load incidence are controversies. Papers have shown that occlusion stress concentrates at the cervical region (SPRANGER ${ }^{25}$, 1995; PALAMARA et al. ${ }^{19}$, 2000; LITONJUA et al. ${ }^{16}$ 2004). Moreover, the same stresses may be generated on restorations placed in the cervical region, and problems in obtaining and maintaining a seal between restoration and tooth have been found to be a primary reason for failure of Class V resin composite restorations (ERIKSEN \& PEARS $\left.^{6}, 1978\right)$. Although many authors have investigated the mechanical forces that influence in Class V microleakage (MANDRAS et al. ${ }^{17}$, 1991; RIGSBY et al. ${ }^{21}$, 1992; DAVIDSON \& ABDALLA ${ }^{4}$, 1994), the load cycling influence in marginal integrity remains unclear.

So, the aim of this research was to evaluate the load cycling influence on Class $\mathrm{V}$ marginal microleakage localized in the enamel/cementum junction using two different composites with their respective adhesive systems. The null hypothesis was that there is statistically significant difference in microleakage between the loaded samples and the unloaded ones. Moreover, this study evaluated the microleakage differences between enamel and cementum margins.

\section{MATERIALS AND METHODS}

Forty bovine incisors were stored, after extraction, in physiologic solution with $0.1 \%$ thymol until use. The cavity preparation consisted of a labial type $\mathrm{V}$, with the gingival wall in cementum and the incisal wall in enamel. A high-speed hand-piece (Kavo do Brazil S.A., Joinville - SC, Brazil), adapted to a microscope base, was used to standardize the cavity preparation. The access was produced using a 1090 diamond bur
(K.G. Sorensen, São Paulo - SP, Brazil) and the final shape with 245 carbide bur (S.S. White, Rio de Janeiro - RJ - Brazil). The cavity configuration was $1.5 \mathrm{~mm}$ deep, $3.0 \mathrm{~mm}$ long and $3.0 \mathrm{~mm}$ high. After every five cavity preparations each bur was substituted. A digital caliper (Mitutoyo, Japan) was used to control cavity standardization.

The teeth were randomly distributed into four groups as follows $(\mathrm{n}=10)$ :

- Resin composite Filtek Z250 (3M/ESPE, Brazil) and Single Bond (3M/ESPE, Brazil) adhesive system;

- Resin composite Charisma (Heraeus Kulzer) and Gluma One Bond (Heraeus Kulzer) adhesive system;

- Resin composite Filtek Z250 (3M/ESPE, Brazil) and Single Bond (3M/ESPE, Brazil) adhesive system submitted to load cycling.

- Resin composite Charisma (Heraeus Kulzer) and Gluma One Bond (Heraeus Kulzer) adhesive system submitted to load cycling.

The materials' compositions are shown in Picture 1 .

Enamel and dentin surfaces of all the preparations were etched using 37\% phosphoric acid gel for 15 seconds, rinsed for 30 seconds, and gently dried with absorb paper (wetting bond technique). Following the manufacturer's instructions, both Single Bond and Gluma One Bond were applied in two consecutive coats to the prepared surfaces and dried gently for 5 seconds before being light-cured for 10 seconds.

All cavities had been restored using the oblique incremental technique. The first increment was accommodated in the gingival wall, with less than $2.0 \mathrm{~mm}$ deep and light-cured for 20 seconds. The second increment was accommodated in the incisal wall and light-cured for 20 seconds. Finally, the third increment was accommodated over the first two ones and light-cured for 20 seconds (all the restorations were carried out by the same operator). The increments were light-cured with the Ultralux Eletronic device (Dabi Atlante, Ribeirão Preto - SP, Brazil) with light intensity around $650 \mathrm{~mW} /$ $\mathrm{cm}^{2}$, checked after every ten restorations, with the Curing Radiometer Model 100 (Demetron Research Corporation, Danburg CT, USA). The restorations were primarily finished with number 12 scalpel to remove possible excesses of restoration in the 
Picture 1 - Materials' compositions

\begin{tabular}{|c|c|}
\hline Material & Composition \\
\hline $\begin{array}{c}\text { Single Bond } \\
\text { Batch \# 3HD } \\
\text { Gluma One Bond } \\
\text { Batch \# 205467 } \\
\text { Resin composite Filtek Z250 } \\
\text { Batch \# 1BA (1400A2) } \\
\text { Resin composite Charisma } \\
\text { Batch \# 010072 }\end{array}$ & $\begin{array}{l}\text { Solution of water, ethanol, HEMA, BisGMA, } \\
\text { dimetacrylates, photoinitiator system and a } \\
\text { methacrylate functional copolymer of } \\
\text { polyacrylic and polyitaconic acids. } \\
\text { Solution of acetone, metacrylates and a } \\
\text { photoinitiator system. } \\
\text { Matrix: Bis-GMA, UDMA, Bis-EMA. } \\
\text { Filler: Zircon/silica: } 60 \% \text { in volume. } \\
\text { Matrix: BIS-GMA } \\
\text { Filler: Barium aluminium fluoride glass, } \\
\text { highly dispersive siliciumdioxide: } 64 \% \text { in volume. }\end{array}$ \\
\hline
\end{tabular}

gingival and incisal walls. The restorations were polished with dioxide aluminum discs Sof-Lex Pop On (3M/ESPE) of all grits. The polishing procedure removed all the excesses of restorative material and care was taken to not remove tooth structure. The roots apexes were sealed with glass ionomer cement (Vidrion R - S.S.White, Brazil). The samples had been coated with nail varnish (three coats) maintaining the restoration and $1.0 \mathrm{~mm}$ from the margins uncovered. The teeth had been embedded in PVC rings (Tigre S.A., Criciúma - SC, Brazil) with chemically activated acrylic resin (Artigos Odontológicos Classico, São Paulo - SP, Brazil), leaving the gingival margin approximately $2.0 \mathrm{~mm}$ above of the edge of the PVC ring.

As next step, with the samples of groups 3 and 4, the incisal edges were ground flat so that the load could be perpendicularly applied to the tooth. During the accomplishment of these steps, care was taken to avoid the dehydration of manipulated teeth. With a machine developed by the researchers, it was possible to carry out the load cycling of the samples. A load of $98 \mathrm{~N}$ was used in this study, as it was considered to be within the normal functional range. The samples had been adapted in the device just beyond the cursor. The cursor was regulated so that it was laying in the incisal edge in a medium position of its ascending and descending trajectory (trajectory of $4.0 \mathrm{~mm}$ ). The cursor, from $2.0 \mathrm{~mm}$ of descending, leaned it the incisal edge, with $10 \mathrm{Kgf}$ load $(98.06 \mathrm{~N})$. Each cycle had 2 seconds dwell time, in a total of 30 cycles per minute. Each tooth was submitted to 1,000 cycles. After that, all the groups were immersed in $2 \%$ buffered methylene blue solution during six hours. So, the samples were rinsed with tap water, brushed using a soft brush, and dried at room temperature and humidity for 24 hours. Each sample was longitudinally sectioned using a Miniton cutter (Struers A/S, Pederstrupvej, Denmark), obtaining two slices. The chosen faces for evaluation were those that presented greater staining. After sectioning, in order to improve the evaluation, samples were polished using $\mathrm{SiC}$ sandpaper of decreasing grit $(320,400,600$ and 1200) on an automatic polisher APL-4 (Arotec Ind. Com., Cotia - Brazil). The infiltration was verified through a stereomicroscope Meiji EMZ-TR (Meiji Techno Co. LTD. Tokyo-Japan), of $45 \mathrm{X}$ magnification, and registered as scores: $0-$ no penetration; 1 -staining of less than $1 / 3$ of the gingival and/or incisal wall; 2 - staining of less than $2 / 3$ of the gingival and/or incisal wall; and 3 - staining until the axial wall toward the pulp chamber. Three calibrated examiners were selected for evaluation. The data were tabulated and submitted to Kruskal-Wallis' test with confidence of $5 \%$.

\section{Results}

Pictures 2 and 3 present the scores of microleakage with resin composite Z250 and resin composite Charisma, respectively.

There were no differences ( $\mathrm{p}>0.05)$ among the groups restored with Z250/Single Bond and the 
Picture 2 - Microleakage of resin composite Z250 (number of samples by score)

\begin{tabular}{|l|cccc|}
\hline \multicolumn{1}{|c|}{ Group } & & \multicolumn{3}{c|}{ Scores } \\
\cline { 2 - 5 } & & 0 & 1 & 2 \\
\hline 1. Enamel/unloaded & 6 & 3 & 0 & 1 \\
2. Enamel/loaded & 4 & 4 & 1 & 1 \\
3. Cementum/unloaded & 1 & 0 & 0 & 9 \\
4. Cementum/loaded & 0 & 1 & 2 \\
\hline
\end{tabular}

Picture 3 - Microleakage of resin composite Charisma (number of samples by score)

\begin{tabular}{|c|c|c|c|c|}
\hline \multirow{2}{*}{ Group } & \multicolumn{4}{|c|}{ Scores } \\
\hline & 0 & 1 & 2 & 3 \\
\hline 1. Enamel/unloaded & 10 & 0 & 0 & 0 \\
\hline 2. Enamel/loaded & 6 & 3 & 1 & 0 \\
\hline 3. Cementum/unloaded & 3 & 2 & 0 & 5 \\
\hline 4. Cementum/loaded & 1 & 1 & 2 & 6 \\
\hline \multicolumn{5}{|l|}{ Codes (for tables 2 and 3 ). } \\
\hline \multicolumn{5}{|l|}{$0:$ with no penetration } \\
\hline \multicolumn{5}{|l|}{1 : staining of less than $1 / 3$ of the gingival and/or incisal wall } \\
\hline 2: staining of less than $2 / 3$ of the gingival and/or incisal wall & & & & \\
\hline 3: staining until the axial wall in direction to the pulp chamber & & & & \\
\hline
\end{tabular}

groups restored with Charisma/Gluma One Bond, for loaded and unloaded groups when restorations were located in enamel and cementum margins (Tables 1 and 2).
When comparing enamel and cementum, in the same group (Tables 1 and 2), there were statistically differences $(\mathrm{p}<0.05)$ between enamel and cementum margins for loaded and unloaded samples. 
Table 1 - Mean post of the groups restored with resin composite Z250

\begin{tabular}{ccc} 
& Unloaded & Loaded \\
\hline Enamel & $11,40 \mathrm{a}, \mathrm{A}$ & $13,85 \mathrm{a}, \mathrm{A}$ \\
\hline Cementum & $28,95 \mathrm{~b}, \mathrm{~A}$ & $27,80 \mathrm{~b}, \mathrm{~A}$ \\
\hline
\end{tabular}

Numbers followed by different small letters in the column and capital letters in rows differ statistically by the Kruskall-Wallys' analysis (5\%).

Table 2 - Mean post of the groups restored with resin composite Charisma

\begin{tabular}{ccc}
\hline & Unloaded & Loaded \\
\hline Enamel & $10,50 \mathrm{a}, \mathrm{A}$ & $16,15 \mathrm{a}, \mathrm{A}$ \\
\hline Cementum & $25,35 \mathrm{~b}, \mathrm{~A}$ & $30,00 \mathrm{~b}, \mathrm{~A}$ \\
\hline
\end{tabular}

Numbers followed by different small letters in the column and capital letters in rows differ statistically by the Kruskall-Wallis analysis (5\%).

\section{Discussion}

Bovine teeth were used in the present study because the studies in the literature have disclosed comparable results mainly to the human teeth in vitro (NAKAMICHI et al. ${ }^{18}, 1983$; REEVES et al. ${ }^{22}$, 1995). Moreover, Kubo et al. ${ }^{13}$ (2001) speculated that seems to be no differences in stress distribution between bovine and human incisors under load cycling.

Kubo et al. ${ }^{13}$ (2001) used repeated buco-lingual loading and suggested that buco-lingual loading could possibly generate greater tensile stress at the adhesive interface than axial loading; which may result in bond degradation. The authors attributed this fact to a flexural load incidence to the teeth. According to Heymann et al. ${ }^{11}$ (1991), factors related to the dental flexure could be significantly associated to retention failures of type $\mathrm{V}$ composite restorations. However, in the present study, since the teeth were fixed to a rigid base, during the compressive load, the teeth were indirectly submitted to a flexural load. Moreover, the etiology of non-carious cervical lesions indicated that incisal or occlusal loads might induce compressive stress at the dentin-enamel junction in the cervical region (LEE \& EAKLE $\left.{ }^{14}, 1984\right)$ and the plastic or elastic deformation of restored teeth by these tension could lead to bond failure at the margins of the restorations (QVIST $\left.{ }^{20}, 1983\right)$.

Previous leakage studies combined with load cycling have given inconsistent results. Some reports showed increased microleakage of resin composite restorations under load cycling while others recorded that load cycling did not affect the marginal integrity. These differences found in in vitro studies can be related to differences in tested materials, load magnitude and its application method, cavity preparation and/or evaluation technique (DAVIDSON \& ABDALLA ${ }^{4}$, 1994; KUBO et al. ${ }^{12}$, 1998). Li et al. ${ }^{15}$ (2002), who used 5,000 cycles of 90N, didn't find different behavior in nanoleakage in cervical restorations between cycled and non-cycled samples restored with three different self-etching adhesive systems (Unifil Bond, Clearfil SE Bond and Prompt L-pop) and a "one bottle" total etching adhesive system (Single Bond). However, Davidson \& Abdalla ${ }^{4}$ (1994), found differences in microleakage between cycled and non-cycled groups, using 5,000 cycles of 125 and $250 \mathrm{~N}$. It is possible to exist a direct relation between the number of cycles and marginal infiltration degree. This ralationship was not verified in this study, probably due to the number of cycles used, which was not sufficient to promote any difference between loaded and unloaded samples. The purpose of this study was to verify the premature 
bond strength under low mechanical cycle without any conideration in relation to the fatique occurred in ultimate mechanical cycles.

Comparing the infiltration degree in enamel and cementum margins, in the same sample, the staining solution penetration was higher in cementum margins, for both loaded and unloaded samples. As several researches have demonstrated that adhesive strength is lower in cementum substrate than in enamel (YAP et al. ${ }^{26}, 1998$; FRUITS et al. ${ }^{9}, 2002$ ), higher leakage can be expected in margins located in cementum (SIDHU \& HENDERSON ${ }^{24}, 1982$; DAVIDSON et al. $.^{5}, 1984$ ). One hypothesis is that despite the use of the oblique incremental technique which was applied to decrease the tension generated by $\mathrm{C}$-factor through the reduction of composite volume (FEILZER et al. ${ }^{7}, 1987$; YOSHIKAWA et al. $\left.{ }^{27}, 1999\right)$, since the cavity used in the present study had a high C-factor, shrinkage is inherent in current commercially available systems and will persist until non-shrinkage or low-shrinkage polymers or expanding fillers are available in commercial composites (SAKAGUSHI $\left.{ }^{23}, 1999\right)$. So, in cementum margins this polymerization shrinkage probably exceeds the adhesive strength and created a gap where the solution had penetrated.

The comparison between the resin composites wasn't the aim of the study since each material was used with it's respective adhesive system and the results could be doubtful since they could be attributed to differences between the elastic moduli of the composites or to differences among the adhesive strength of adhesive systems. The adhesive systems Single Bond and Gluma One Bond were used because both of them are based in the total etching technique, with primers based in alcoholic solvents. Moreover, resin composites Z250 and Charisma are characterized as hybrid composites, with similar polymerization shrinkage and filler volume content.

\section{Conclusions}

Load cycling did not increase the microleakage in enamel or in cementum margins with 1,000 cycles.

Comparing the infiltration degree in enamel and cementum margins, in the same sample, the staining solution penetration was higher in cementum margins, for both loaded and unloaded groups.

\section{Resumo}

O objetivo desta pesquisa foi avaliar a influência da ciclagem mecânica em restaurações de compósitos através da análise de infiltração marginal, no esmalte e cemento. Quarenta incisivos bovinos foram separados em quatro grupos ( $\mathrm{n}=10)$ : I - Z250/Single Bond; II - Charisma/Gluma; III - Z250/ Single Bond submetido a 1.000 ciclos (10Kgf); grupo IV - Charisma /Gluma submetido a 1.000 ciclos. As restaurações Classe V foram realizadas na junção esmalte-cemento e a carga foi aplicada na borda incisal. As amostras foram imersas em solução tamponada de azul de metileno a $2 \%$. As amostras foram seccionadas e a infiltração foi avaliada, através de scores, com estereomicroscópio (45 X). Os dados foram submetidos ao teste de Kruskal-Wallis (5\%). A análise não mostrou diferença estatística entre as margens localizadas no esmalte ou no cemento, nos grupos ciclados e não-ciclados ( $\mathrm{p}>0.05$ ). Entretanto, o esmalte mostrou resultados melhores do que cemento na mesma amostra $(\mathrm{p}<0,05)$. A ciclagem mecânica não aumentou a microinfiltração no esmalte ou em cemento. Comparando o grau do infiltração na mesma amostra, a penetração da solução foi maior em cemento, tanto para os grupos ciclados como para os não-ciclados.

\section{UNITERMOS}

Resinas compostas; mecânica, ciclagem microinfiltração 


\section{References}

1. Anusavice KJ. Phillip's Science of Dental Materials. 10th ed. Philadelphia: Saunders; 1998.

2. Asmussen E. Composite restorative resins. Composition versus wall-towall polymerization contraction. Acta Odontol Scand 1975;33(2):33744.

3. Crim GA, Garcia-Godoy F. Microleakage: the effect of storage and cycling duration. J Prosthet Dent 1987;57(5):574-6.

4. Davidson CL, Abdalla AI. Effect of occlusal load cycling on the marginal integrity of adhesive Class V restorations. Am J Dent 1994;7(2):111-4.

5. Davidson CL, de Gee AJ, Feilzer A. The competition between the composite-dentin bond strength and the polymerization contraction stress. J Dent Res 1984;63(12):1396-9.

6. Eriksen HM, Pears G. In vitro caries related to marginal leakage around composite resin restorations. J Oral Rehabil 1978;5(1):15-22.

7. Feilzer AJ, de Gee AJ, Davidson CL. Setting stress in composite resins in relation to configuration of the restoration. J Dent Res 1987;66(11):1636-9.

8. Ferracane JL. New polymer resins for dental restoratives. Oper Dent 2001;6 (Sp.Iss 1):199-209.

9. Fruits TJ, VanBrunt CL, Khajotia SS, Duncanson MG Jr. Effect of cyclical lateral forces on microleakage in cervical resin composite restorations. Quintessence Int 2002;33(3):205-12.

10. Guggenberger R, Weinmann W. Exploring beyond methacrylates. Am J Dent 2000;13(Sp.Iss):82D-84D

11. Heymann HO, Sturdevant JR, Bayne S, Wilder AD, Sluder TB, Brunson WD. Examining tooth flexure effects on cervical restorations: A two-year clinical study. J Am Dent Assoc 1991;122(6):41-7.

12. Kubo S, Konishi Y, Yokota H, Hayashi Y. Effect of cavity forms on microleakage of cervical restorations under loading [abstract n.2071]. J Dent Res 1998;77(Sp.Iss):890.

13. Kubo S, Yokota H, Sata Y, Hayashi Y. The effect of flexural load cycling on the microleakage of cervical resin composites. Oper Dent 2001;26(5):451-9.

14. Lee WC, Eakle WS. Possible role of tensile stress in the etiology of cervical erosive lesions of teeth. J Prost Dent 1984;52(3):374-80.

15. Li H, Burrow MF, Tyas MJ. The effect of load cycling on the nanoleakage of dentin bonding systems. Dent Mat 2002;18(2):111-19.

16. Litonjua LA, Bush PJ, Andreana TS, Tobias, Cohen RE. Effects of occlusal load on cervical lesions. J Oral Rehabil 2004;31(4):225-32.
17. Mandras RS, Retief DH, Russell CM. The effects of thermal and occlusal stresses on the microleakage of the Scotchbond 2 dentinal bonding system. Dent Mater 1991;7(1):63-7.

18. Nakamichi I, Iwaku M, Fusayama T. Bovine teeth as possible substitutes in the adhesion test. J Dent Res 1983;62(10):1076-81.

19. Palamara D, Palamara JE, Tyas MJ, Messer HH. Strain patterns in cervical enamel of teeth subjected to occlusal loading. Dent Mater 2000;16(6):412-9.

20. Qvist $\mathrm{V}$. The effect of mastication on marginal adaptation of composite restorations in vivo. J Dent Res 1983;62(8):904-6.

21. Rigsby DF, Retief DH, Bidez MW, Russell CM. Effect of axial load and temperature cycling on microleakage of resin restorations. Am J Dent 1992;5(3):155-9.

22. Reeves GW, Fitchie JG, Hembree Jr JH, Puckett AD. Microleakage of new dentin bonding systems using human and bovine teeth. Oper Dent 1995;20(6):230-5.

23. Sakagushi RL. A review of the curing mechanics of composites and their significance in dental applications. Compendium 1999;20 (Sp. Iss n.25):S16-S23.

24. Sidhu SK, Henderson LJ. Dentin adhesives and microleakage in cervical resin composites. Am J Dent 1982;5(5):240-4.

25 . Spranger $H$. Investigation into the genesis of angular lesions at the cervical region of teeth. Quintessence Int 1995;26(2):149-54.

26. Yap AU, Ho KS, Wong KM. Comparison of marginal sealing ability of new generation bonding systems. J Oral Rehabil 1998;25(9):66671.

27. Yoshikawa T, Sano H, Burrow MF, Tagami J, Pashley DH. Effects of dentin depth and cavity configuration on bond strength. J Dent Res 1999;78(4):898-905.

Recebido em: 27/05/04

Aprovado em:23/08/04

Prof. Dr. Simonides Consani Departamento de Odontologia Restauradora; Área Materiais Dentários UNICAMP - Faculdade de Odontologia Av. Limeira 901, Caixa Postal 52; CEP - 13414-903, Piracicaba - SP - Brazil

Phone number: 55-19-34125345 e-mail: consani@fop.unicamp.br/schneider@fop.unicamp.br 